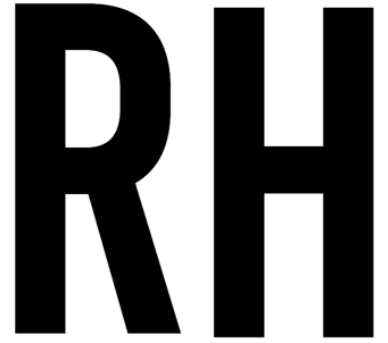

RADICALHOUSINGJOURNAL

\title{
Imploding activism: Challenges and possibilities of housing scholar-activism
}

\author{
Pratichi Chatterjee \\ University of Sydney \\ Jenna Condie \\ Western Sydney University
}

\author{
Alistair Sisson \\ University of Sydney \\ Laura Wynne \\ University of Tasmania
}

Contact:

pratichi.chatterjee@sydney.edu.au

\begin{abstract}
This paper traces our scholar-activist work with resident groups that arose in response to the redevelopment of a public housing estate in Sydney, Australia. Over the two-year period of our involvement, the groups' capacities to contest the redevelopment were gradually destabilised and neutralised by pressure from state actors and through intra-group tensions. In other words, the activism imploded and we were imbricated in that process. In this paper, we apply an autoethnographic method of 'writing-as-inquiry', which draws upon our correspondence with one another as data, to chart the challenges and possibilities for academics working within urban activism. Firstly, we are critical of ourselves for treading (too) carefully, which meant that we failed to challenge gendered, racialized and classed group hierarchies, and failed to support more radical and resistant positions to state authorities.

Secondly, we highlight the power that individual actors can have to derail an activist group. Place-based activism necessarily means that people of varied political leanings and ideological dispositions will come together. It also means that people of diverse, and sometimes antagonistic personalities, will encounter one another. Thirdly, we point to the hostile and destructive context provided by the neoliberal city and, increasingly, the neoliberal university. We propose that when engaging in activism, academics should determinedly de-centre the self and centralise activist aims as they work to balance the objectives on both sides of the scholar-
\end{abstract}


activist hyphen. We deliberate the role academics can play in mediating the conflicts that arise in activism, and the repercussions of such a direction, which inevitably means accepting the messiness of activism, and as Haraway has put it, 'staying with the trouble'.

\section{Keywords}

scholar activism, housing struggles, solidarity politics, urban renewal, resistance

\section{Introduction}

Scholar-activism can be a fraught and frustrating process; so too activism and scholarship in general. In the same way that the results of 'failed' scientific experiments are rarely reported in spite of their utility to the 'field', writing on activism and resistance is broadly critical yet tends to focus more on the positive and productive experiences as though it is these that provide the most insight. Our experiences in a struggle over a public housing estate in Sydney were to the contrary; the failures - our failures - have been more instructive than the successes. In this paper, we consider the processes and outputs of our researchresident-activist work. Our aim is not to dissuade or to caution; while housing justice is a prevalent theme in the scholar-activist and participatory action research literature (e.g Arthurson et al. 2014; Martínez López 2013; Oldfield 2015), too many social researchers have problematically built and continue to build their careers by studying the lives of people who have been socio-economically disadvantaged while eschewing their struggles (Chatterton et al. 2010). Therefore, our aim is to illuminate some of the hazards that scholaractivists can face when deeply involved in housing activism and provide routes for how they might work through them.

We draw on our 18-24 month long involvement with resident activist groups who were (at first) resisting an estate redevelopment. In our reflexive account, we attempt to avoid 'narcissistic self-centering which locates myself-as-author at the centre of an heroic or romanticised narrative' (Routledge, 1996, p. 401) — a difficult task given that we are all researchers writing together without the input of others involved as activists. Yet coproduction and democratic forms of research have been criticised, and furthermore, as Maxey (1999, p. 202) argues, we can not ever fully explicate 'the entire landscape of power' through the methodological tools of reflexivity, and those who claim to do so reproduce the problematic 'god-trick' of colonial knowledge systems and negate their position as researchers tied to powerful institutions often writing in relative isolation from 'nonacademics' involved in the activism recollected.

In our writing, we endeavour to take a critically reflexive focus on structural relationships_of political, socio-economic and institutional processes_as well as those of positionality (Nagar \& Geiger, 2007). ${ }^{1}$ To this end, our focus is on the difficulties of

\footnotetext{
${ }^{1}$ To this end, it is critically important to recognise the 'baggage' we carry as academics (Routledge \& Derickson, 2015), particularly in the specific geographical context in which we have been active. This baggage comes in two pieces: a legacy of exploitative (over)research in the community and of public housing tenants
} 
managing the power distributions between researchers and research subjects, between different people who hold varying levels of privilege as a consequence of gendered, classed and racialized hierarchies. We have undertaken this through a process of 'writing as enquiry' (Richardson \& St Pierre, 2005), writing a series of journal-style reflections for one another to read, discuss and together produce an account that conveys an entangled but not necessarily consensual understanding of what happened and what might become in our research and activism. Our reflections are interspersed throughout this paper alongside the themes they correspond to- these excerpts are indicated in italics throughout. We see our writing to one another as a practice of a 'feminist ethics of care' (Gilligan, 1985), and of taking on accountability (Bakhtin, 1984) or 'response-ability' for 'the stories we use to tell stories with' (Haraway, 2016, p. 12).

Three core issues frame our (in)action as researcher-outsiders to the action groups and speak to the broader challenges of place-based activism. Firstly, there was the difficulty of addressing the problematic leadership structures of the groups in a way that did not appropriate their struggles. Secondly, we identify the potential for destructivity carried by individual actors; while analyses often seek to separate the 'generalisable' from the 'particular', individual identities, personalities, politics and ideologies are crucial to activism's success or otherwise. Finally, we situate our experiences within the hostile environments of the neoliberal university and city, and sketch some directions and possibilities that we are seeking to pursue, and that others might seek too.

\section{Ethics and appropriation}

'My voice has sometimes been elevated above those of tenants, to that of the 'expert' (which I make no claim to being). The 'expertise' of outsider professionals has at times stifled tenant engagement. One group's chair will, for instance, often ask an outsider professional directly for a contribution on a particular point raised during a meeting. Such moments of privileging seem to signal to tenants that outsiders have a special status and a more important role to play in the tenants' struggle for housing justice.'

Among the four of us were manifold motivations that drew us to the public housing estate: three of us (Pratichi, Laura, Alistair) were beginning doctoral research projects on public housing, redevelopment and housing activism; two of us (Jenna, Alistair) live/d in neighbouring suburbs; all four of us were angered by the proposed redevelopment and the manner in which it was announced. These emotions and core values were perhaps the most powerful motivating forces; we were moved by anger and a sense of 'response-ability' (Haraway, 2016, p. 12) to do more than sit silently in the wake of gentrification. 'Being moved' in such a way was crucial to our participation; Derickson \& Routledge (2015, p. 3) convincingly argue against the immobilising weight of 'being overly analytical, overly reflexive, or overly cautious'. However, we suggest that it is simultaneously possible to be too eager to dive into activism in a researcher or outsider capacity; it is all too easy to be swept up by currents that drag in a direction that you never intended to travel where the

more broadly, and complicity of (at least one of) our institutions in the gentrification of this community's neighbourhood. 
work you do ends up contributing to, and perpetuating the problem (Ahmed, 2012). In writing our recollections, we figured that we had been too careful and trod too lightly so as not to leave footprints in the ground given our 'politics of location' (Braidotti, 2006, p. 199): we are not from the land and living in the community that we seek to support. We could have taken a different tack and willingly imbricated ourselves more deeply in the tensions and troubles of activism. But then what would have become? What happens when you stamp your feet, raise your voice, step away from the safety of your 'outsider' position and step into direct confrontation?

From the outset when we engaged with the tenants' groups, our key concern was to do activism with, not for, public housing tenants so as not to overstep our place. We were heeding the warning to pay close attention to uneven geometries of power where despite a prior commitment to co-research, Chatterton et al. (2010, p. 259) ended up 'effectively running' a campaign to prevent the demolition and private redevelopment of a housing estate in Leeds (UK), fostering a dependent relationship with the tenants that, after the researchers 'ran out of steam' in their attempts to mobilise tenants, led to the campaign's collapse (ibid., p. 259). Like Chatterton et al., we remained hyper-aware that the homes of the estate are not our homes, though we acknowledge that the fight for the neighbourhood is also our 'responseability' (Haraway, 2016, p. 12) in the wider context of unaffordable housing and hasty development in the city we call home.

'My involvement with the groups has been motivated primarily through my research interests in the field of urban geography but also through my political convictions, and the solidarity I feel with other urban residents, especially on the issue of affordable housing or the lack thereof in the city.'

Furthermore, we were fearful of perpetuating an exploitative and (neo)colonial relation between researchers and participants (especially those positioned as marginalised or disadvantaged by societal institutions such as government and media) that has persisted for centuries in the social sciences as well as the wider academy.

We were also wary of the power imbalances at play, given our position as (vaguely) middle-class outsiders. These identities-middle-class, academic, and outsiderpredominantly defined how we initially saw ourselves in relation to the groups, and they continued to shape our actions in troublesome ways. During this initial period, we were acting as 'supplicant' researchers, uncritical of the 'resisting others' we had aligned ourselves with (cf. Derickson \& Routledge, 2015; Routledge, 1996, p. 407).

'My working-class-ness gives me a positionality that many other housing academics do not have. Yet I also live 200 metres up the road from the estate in a privately-rented apartment, entangled in the very processes that are pushing public housing tenants out of the inner city.'

'My position as a middle-class academic who does not live in the area, makes me question the ethics of my practice. Is this information only going to be of direct benefit to me and my research aspirations? In which case I am essentially preying on other people's situations and using that to my advantage. The structural violence to which they are being subjected, benefits my research and in turn the university, which has played a role in the gentrification of surrounding neighbourhoods, including this one.' 
It bears noting that, despite undergoing rigorous ethics review processes to undertake our research, the 'real ethics' challenges that we faced in our research 'never seemed to have a box on the form' in formal ethics processes (Gillan \& Pickerill, 2012, p. 134). Our university ethics procedures (which assume clinical conditions that can be controlled, rather than the dynamic and unpredictable experiences of participating in a social movement) ignored the need to navigate scenarios in which there is no 'right choice' and in which conditions change rapidly (ibid., p. 135). Actual ethical considerations were not something that could be predicted and managed upfront, but, as described by Gillan and Pickerill, were rather a 'dynamic, ongoing, and complex dilemma' that we faced continually throughout our involvement, including after most of our 'data' was collected (ibid., p. 135). These challenges related less to securing informed consent, ${ }^{2}$ and more to questions of our allegiance to the groups we worked with: to what extent did we have a responsibility not just to ensure they were informed and willing participants in our research, but to navigate (and intervene on) intra-group relationships? In other words, our challenge was not merely to consider our relationship with research participants, as we were confronted with difficult relationships within the groups of residents and housing activists. Should we be passive observers, 'neutral' researchers, and stand by while these problematic events played out? Or should we intervene, taking a more active role in steering the groups' dynamics?

The uneven power distributions of race, class and gender came to the surface again and again and again, in the way meetings were run, who made decisions, the distribution of responsibilities and whose voices were heard. At group meetings, a condescending and dismissive attitude towards women, women of colour and working-class residents was particularly visceral. On other occasions, we knew that information being disseminated by resident leaders on the government's redevelopment program was inaccurate—and, at times, false. In a place where rumours circulated swiftly through the grapevine, false information regarding housing demolition and relocation has the potential to be very damaging, causing great stress for residents. We were often witness to such events, but we found that intervening in a productive way was difficult.

Our challenge was to perform scholar-activist roles 'on both sides of the hyphen' (Routledge \& Derickson, 2015, p. 391). We were so concerned about our scholarly identities and so careful to check our class privileges that we failed at times to practice our activist role, which might, had we embraced this role, have involved standing up for and creating space for voices that were being silenced. In taking care not to allow our own voices to become dominant, we created a space in which other relations of dominance and oppressionpatriarchal, ageist and race-based relations, in particular-flourished.

There were many interrelated reasons behind our reluctance to interfere. We were fearful that we might 'take over' the groups and their activities, and that our particular skills

\footnotetext{
2 As Maxey (1996) has noted, when a researcher relates to their participants as something other than that of 'researcher', be it friend, acquaintance or fellow activist, 'informed consent' takes on a different hue. In our experiences and Maxey's, residents did not necessarily see themselves as participants in a research interview but as interlocutors with a familiar person; as such, our prefaced comments about consent were often waved away.
} 
in navigating political and bureaucratic processes would position us in more central decisionmaking roles than the tenants, who we felt should be at the heart of the action. We were concerned that we might steer things in a direction away from what tenants wanted, and that they might not speak up if and when this occurred. As doctoral students and academics paid to do research, we were vigilant not to impose our politics and ideas on people who did not hold a financially- or socially-privileged position (cf. Chatterton et al., 2010). Most people involved in this activism were above the age of 60 , and many had not previously engaged in political activism. Deploying feminist and anti-racist tropes that are in frequent circulation in young, middle class and university educated circles to 'call out' working class residents or change the quality of their activism might have reinforced existing power differentials between 'them' and 'us'. This speaks to a larger issue: we did not see anti-racism and feminist work as a core part of the activists' work: the focus of concern was a redevelopment project that would see working class homes and communities destroyed. Furthermore, as researchers we feared that we would jeopardise our relationships with (prospective) research participants by speaking up against (and potentially putting offside) dominant actors within the groups.

The question is how do we navigate such a terrain where we do not usurp the activist work of resisting 'others' but where we still wish to practise a certain ethics and politics rooted in the ideals of anti-racism, class-equality and feminism etc.? We did not want to appropriate or 'take over' the activism of the tenants, but we simultaneously have ethical obligations to intervene when our core values are at stake. Several scholar-activists have grappled with these issues. For many, the issue is one of deconstructing artificial boundaries; as Nagar \& Geiger (2007, p. 268) argue, feminism 'is committed to challenging pre-given social categories [but] an emphasis on "positionality" requires reference to those very categories'. In this vein, Chatterton et al. (2010, p. 247) call for a rejection of the 'false distinction' between academia and wider society. Similarly, Routledge and Derickson contend that scholars 'make too much of the structural distance' between themselves and the social movements that they work with (2015, p. 392) and advocate that activists and scholar-activists need to rework the 'artificial boundaries' that we build between spaces of scholarship and spaces of activism. While we acknowledge that the distinction is unhelpful to some extent, it is important to understand the differentiated power held by those in different subject positions.

Nagar and Geiger (2007, p. 270-271) offer some insight on working differently with NGOs where they adopted a process of critical internal reflexivity focused, among other things, on the ability of group members to challenge their own prejudices. The approach sparked difficult conversations about patriarchy, casteism and communalism. In their 'speaking with' model, both researchers and research subjects are expected to implement a method of 'talking and listening carefully' that entails an openness to the influences of people from different socio-cultural locations. Featherstone (2003) similarly implores us to see activism as an opportunity not just to bring together people with common interests but as generative: an opportunity to reshape political identities. Scholar activists may wish to use such a model to not only practice self-reflexivity for themselves, but to also encourage such a practice among dominant and privileged non-academic members within the political 
groups they are supporting. Social hierarchies manifest along multiple axes, but in our activism we were overwhelmed by those that exist between academics and non-academic research participants who did not hold the similar socio-economic positions to ours. Instead, what was needed was a group-reflexivity that is intersectional in nature.

A major caveat to such a project is that it requires long-term relationships and political engagement between researchers and research participants where the levels of commitment on the side of the researchers cannot be shallow. Such an endeavour also relies on the trust and collaboration of those members who feel marginalised by the existing power dynamics within a group and who wish to take ownership of a such a process of reflexivity in order to hold their leadership as well as their academic allies to account. Creating these long-term trusting relationships is, however, increasingly fraught in neoliberal academic settings where $\mathrm{PhD}$ programs have been shortened, funding is limited and the casualisation of academic labour has become the norm forcing people to take on multiple workloads, at least in 'Western' countries.

In hindsight, our reflections here help us see that we might have pushed harder to influence the activists, given our privileged position as academics. We might see scholar and activist relationships not as perpetually hindered by historical and contemporary power relations, but instead as an opportunity to remake relations in ways that are caring and productive; a difficult, but not impossible, task.

Despite the balancing act of avoiding appropriation, we must also recognise the contributions that we could — and did-make as academics to the groups we politically engaged with. Chatterton et al. (2010, p. 263) pay attention to this 'emancipatory potential' in their principles for scholar activism. We organised supportive digital/social media workshops for residents, integrated the opinions of different community members into a submission to a tribunal on social and affordable housing, contributed to a tenant's handbook, and directed the material resources of the university, such as printers and computers, towards local activism. In Routledge and Derickson's words (2015, p. 1) our actions worked to resource community groups by directing some of the privileges and resources provided to academics, such as access to technology, time and training in writing and analysis, towards non-academic collaborators.

\section{The power of the individual in activism}

When a place is threatened by redevelopment, residents often come together in their shared sense of belonging and place attachment—which may be all that they share. It takes more than a collective sense of place for an action group to function well and effectively. Unfortunately, while there has been considerable research on collective engagement and groundswell in place-based activism, less is known about the specific role of individual activists and how they operate within groups and social movements (Curtin \& McGarty, 2016; Postmes \& Smith, 2009). As Subašić et al. point out, 'individual differences do not simply disappear or become completely irrelevant once people start to define themselves in terms of their membership of a particular social (psychological) group' (2008, p. 337). We 
bore witness to, and participated in, some inspiring encounters across difference (diverse politics, ideologies, values, identities, and vested interests) that were generative of knowledge, mutual understanding, care, solidarity and action. However, we also tolerated and enabled the centralisation of action, power, and voice in, effectively, a single person. That person was far from representative of the activists and indeed, the wider community, and we struggled to address gendered, racialized and classed hierarchies that arose from the very unequal power relations in play.

'This community is not all white. Yet time and time again, at activist meetings, at community workshops, official 'engagement' events, in the newspapers, older white men are speaking, leading, deciding, directing, and dominating discussion. There is little space here for women, especially women of colour.'

Social identity theories of collective action often fail to acknowledge how 'advantaged group members tend to occupy more powerful positions in existing power structures than disadvantaged group members' (Curtin \& McGarty, 2016, p. 232). In social identity terms, it makes sense that people with more power-in Australia, this tends to mean white older men - in society rise to leadership roles within housing and urban activism. But 'this is 2018', as Braidotti (2018) repeatedly stressed in a recent public lecture: difference matters and older white men need to make space for others to speak and be heard, and to have influence for progressive action to take place. Within the intra-group relations of the activists, we experienced dilemmas in our solidarity where perhaps our commitment to the cause and the higher-order identity of the campaign (Subašić et al., 2008) coupled with our 'outsider' identities made it difficult to challenge unequal power relations, as well as step away when the activists' stance of resistance was reduced to one of complicity, which in turn, conflicted with our own personal core values. The question becomes what can we do in such problematic circumstances and how can we ensure there is a 'polyphony' of voices (Bakhtin, 1984) within group-based activism that prioritises those with less power in society. It could certainly be more productive if, as scholar-activists, we were better equipped to address intragroup conflicts and avoid consolidations of power into the hands of the typical few.

Taking up the subject-position of 'activist' is not an easy task and it is not one that is available to everyone. It is made more difficult for public housing tenants given the widespread stigmatisation of living in public housing (Arthurson et al., 2014; Palmer et al., 2004). Furthermore, when individual people have much at stake such as their housing security, it can perhaps be easier for government officials and engagement consultants to maneuver individual activists, and in turn collectives and groups, into a partnership mode. Those speaking and acting prominently on behalf of the community then become the precise voice that government officials and redevelopment consultants want and need: a 'partner' (Collins, 1999, p. 79). By making residents feel as though state government and masterplanning officials are their friend, an age-old colonial tactic is enacted which works to justify gentrification and continued colonisation (Munro \& Spring, 2018).

Becoming the 'partner' of the state government is more compatible if activist leaders identify with authority and see opportunities in 'advancing their own interests within the high-status group’ (Postmes \& Smith, 2008, p. 774). Often when oppression occurs within 
groups, it is reinforced systemically through the endorsement of oppressive policies and initiatives (Postmes \& Smith, 2008). When a leading role within a resident group was taken up not by a person with a strong insider status (i.e. a public housing tenant), but by an outsider operating in a professional consultant role, the reinforcement of oppressive and silencing government policies and community engagement practices gained momentum. Attempts were made to keep pace with, and mirror the official planning and consultation process in form, tone and timing so as to be more productive and palatable to state officials, and in turn, gain at least something in the wake of a redevelopment and its aftermath. The language that accompanied the new plan of action for the campaign —of 'stakeholders', 'resilience', 'empowerment' and 'environmental scanning' - echoed the empty rhetoric of the bureaucrats and consultants that tenants and activists had already been alienated by. Such discourses were materially effective in terms of removing residents from activism and bringing resistance to a halt. Furthermore, they advanced 'the narratives that explain socially excluded groups as marginalised, with individuals carrying some responsibility for their disadvantage' (Jacobs, et al., 2011, p. 14).

In scholar-activist mode, we attempted to raise our voices, speaking out against the new interface between the government and residents, and on the regulations by 'outsiders' and their sub-textual accusations of unethical practice on our part. One by one, along with others, we were pushed to the margins.

'What the fuck happened? I'm still not sure. It was like circling a drain pipe; at first spiralling slowly, and then gathering pace before suddenly being sucked into a stream of shit. The activism seemed to get closer and closer to housing officials, closer and closer to accepting whatever they wanted to do while making a pantomime of putting up a fight.'

These sagas are not mere oddities or irrelevant, particular occurrences; they are generally instructive that individual people in activism are important. They have the power to make it and, perhaps more even more so, to break it. We were warned by activists from other public housing redevelopments that somehow, through someone and something, any resistance to estate redevelopment would be quashed. Individual people and what they uniquely bring to activism and how they operate within group contexts warrants further attention. Research has to a large extent focused on the activism of 'low status' groups (Postmes \& Smith, 2009, p. 770) but less so on how individual activists who identify and comply with authority can be addressed within the work of activism.

Conflicts inevitably arise, and if these are not confronted (which is not to say resolved), they will fester and a group may eventually implode. Within a 'community of practice' such as a housing activist group, disagreement and tension are crucial but it must be reconciled for productivity (Lave, 1990; Wenger, 1999). While Chatterton et al. (2007) distinguishes between major differences that require reorientation or subdivision, and minor or personality differences that can be resolved quickly, not all conflicts fit so neatly into these categories. Indeed, not all individual differences and conflicts are easily and quickly resolved. There is a role for scholar-activists to play in mediating such conflicts. This means confronting the messiness and discomfort of activism, and as Haraway (2016, p. 2) has put it, 'staying with 
the trouble'. One tactic, albeit difficult, is to push advantaged group members to critique existing power relations and dynamics, and to be in political solidarity with group and community members who would benefit most from their activism (Subasic et al. (2008). As researchers, we need the ethical tools, protocols and practices that enable us to work differently in research, to make 'oddkin' with other activists as 'we require each other in unexpected collaborations' (Haraway, 2016, p. 4) in order to reimagine the housing system and resist oppressive policies and public housing reform. Indeed, the relationships that were forged in the campaign allowed a new political collaboration to emerge following the campaign's dismemberment. This time the group that formed was a women-led organisation with a strong feminist ethics of care and anti-colonial stance adopted. Like redevelopment (or perhaps unlike it), activism has the capacity to 'regenerate' (Haraway, 2016, p. 151). The women-led housing activism that emerged is well framed as a 'feminist snap', a moment where you can no longer take oppression (Ahmed, 2017, p. 162).

Estate redevelopment is a long and ever-lengthening process: of announcement, consultation, master-planning, backtracking, tendering, delaying, demolition and construction. On the one hand, this could be a fertile time, if activists are so devoted, energetic and resourced as to continue to develop and deepen relationships with one another and with members of the wider community, and to hone and expand their resistance strategies. On the other hand, the redevelopment process is one of exhaustion. Community members are constantly asked to engage with something or other: a narrowly-circumscribed state program of consultation; various non-government and community group workshops and meetings; training and community capacity building, interviews with researchers and journalists. Doing activism amidst these demands and the demands of everyday life requires an enormous amount of time and energy. By atomising residents and demanding their time unremunerated, the consultation process suppresses group activism. It divides and conquers and individual activists need to share their experiences in order for others to better resist the neoliberal hostility that deepens social inequalities and rewards unjust urban redevelopment.

\section{Reorientations and possibilities: Overcoming neoliberal hostility}

Both the narrow and reductive engagement process and the entry of entrepreneurial 'new urbanist'-type consultants into public housing activism are symptoms of the hostile environment that housing activists have to contend with. The redevelopment itself is constructed as a project of city- and state-wide significance, part of a broader neoliberal rollback and roll-out (Peck \& Tickell, 2002) that restructures select public housing estates following an ethos of privatisation, self-sufficiency and the transfer of the governance of public resources to the third sector. In a context of intense stigmatisation of public housing and a housing affordability debate that has been corrupted by developers and propertied interests, mobilising broad-based public support for public housing was difficult, regardless of the activist groups' internal conflicts.

Journalists, activists, architects, planners, and academics (ourselves included) dropped into resident group meetings (often after making initial contact through social media 
channels), sat through a meeting and spoke their piece to a handful of residents. Sometimes they returned; more often they did not. For many, it was heartening to see interested and impassioned non-residents, although there was always an element of concern about the fascination-bordering on exoticisation-that sometimes accompanied this kind of attention. The presence of non-residents was not in itself problematic. Partly, the problem was quantitative; too often the number of 'outsiders' equalled or surpassed the number of residents in attendance. More problematic were the politics and the discourses of some of the people who sought entry: a developer posing as a self-described 'city-maker' who spoke about cooperative housing and community land trusts as an alternative future for the estate; a journalist who was fixated on issues of drugs and crime; a historian commissioned by the government to document 'life on the estate' as a kind of memorial to what was about to be erased; and, a consultant who attempted to formulate an 'alternative' consultation and masterplan that reproduced the state government's line and approach. In the neoliberal city, there are innumerable opportunistic actors seeking to profit or gain cultural capital (and economic capital) and 'social impact' from marginalised groups and their struggles for housing security.

This leads us also towards the neoliberal university; researchers are not immune from such impulses and are under ever-mounting pressure to develop an identity or even a 'brand' as a scholar. However, critical academic thought is also a vast repository of knowledge that has rigorously critiqued and voiced alternatives to existing societal power structures that organise differences of race, bodily abilities, class, sexuality and gender etc. across multiple overlapping hierarchies (Ahmed, 2012; Yuval-Davis, 2015). Such work presents wellthought-through challenges to the present-day neoliberal onslaught we see practised across so many state and private institutions and organisations in the 'Global North' and the 'West', including that of higher education. Scholar-activism can draw on the knowledge base of critical academia to provide challenges and alternatives to the neoliberal sensibilities that may co-opt activism. Of course, academics also pose similar threats, and hence any interventions we make must be conjoined with a healthy dose of self-reflexivity. We cannot 'direct' an activist group towards one path or another. Critical scholar-activism, grounded in an ethos of social justice, is however a collective of important voices that can help challenge neoliberal dominance.

The potential of such critical voices is tempered by the hostile environment of the neoliberal university, with its increasing pressure to publish in highly ranked academic journals, attract prestigious grants, research impact, ever-mounting administrative and teaching workloads, and the necessity for most graduate students of taking on paid research or teaching work to supplement meagre (if awarded) scholarships (cf. Farrow et al., 1995).

'While I feel as though my research project is designed in a way that sits comfortably within the political ideals of the activists, its outputs have (or will have) minimal cachet or potency. As such, it is incumbent upon me to try to develop secondary outputs that may be of some use. Within the neoliberal university, however, these outputs count for little, and we are neither encouraged nor afforded sufficient time to produce them.' 
In the face of corporate disincentives, institutional activism requires a reorientation so as to work across the fertile 'cracks' between academia and the wider social world (Bunge, 1994, in Merrifield, 1995, p. 64; Derickson \& Routledge, 2015). If we can re-orientate our research objectives and ethics frameworks so that our aims as activists and as researchers are not in conflict, activism itself can actually contribute more directly to research and knowledge production. For instance, research objectives can be designed alongside community groups and grass-roots organisations and ethics frameworks can be re-written to centre de-colonial or feminist research methods and ethics. Another, more difficult reorientation needed to support the work of scholar-activism is that of academia's very narrow conceptualisation of research impact. The Australian Research Council defines research impact as the contribution that research makes to the economy, society, environment or culture, beyond the contribution to academic research' (2018, p. 13) measured by research outcomes such as publications and citations, commercial results and job creation, policy change and integration, and the enactment of research findings into new practices. While such impact agendas may not have been designed with the work of scholar-activism in mind, they could perhaps be co-opted for it (Routledge \& Derickson, 2015). How might defining impact not only in terms of research, but also in terms of contributions to activism or community based work, shape the outputs of university academics and outcomes of academic research? What sorts of new knowledge practices would it make possible? Such a reorientation entails a significant shift in how the university values itself, and there is much collective political work to be done, among university staff members and across universities, for this to become a reality.

Building networks across academics participating in activism and community-based work is another vital shift needed in the university space, in order to support and strengthen the effectiveness of scholar-activism by promoting a culture of knowledge sharing. In providing direction for productive scholar-activism, Chatterton et al (2010) emphasise the need for scholars to organise themselves into networks. We note that even on our small scale, we failed to do this in any cohesive way until things began to unravel within the housing groups we were supporting. It was only in the course of such unravelling, that we recognised the need to discuss problematic events and relationships as well as our response to them. But it was too late by that point. Had we worked together to organise and reflect proactively from earlier on in the project, we might have been able to instigate action to prevent the implosion of the campaign and the destructive influence of individual people.

Encouraging an academic-activist pedagogy within universities across multiple disciplines, has the potential to support activism, not only by creating a space for reflection and strategy, but also through the insight that different disciplines can bring. For instance, Jenna's base discipline, psychology, has much to offer scholar-activism in terms of its understanding of intragroup dynamics in activism (see Curtin \& McGarty, 2016, for an overview), whereas urban studies or law could bring in knowledge of navigating planning systems, housing markets and legal issues that activist groups might need to contend with. Some of us have benefitted from existing friendships with researchers across different disciplines who have had significant experience of being embedded in activist groups. For 
those who do not have access to such relationships, creating well-resourced platforms and forums will allow for ideas to be exchanged, difficulties to be talked over and potentially the development of new ways to effectively participate in civil society. Such networks cannot remain solely for the use of academics however, they also need to be brought to the attention of, and made inclusive of non-researcher activists from the community groups we are supporting in order to prevent an exclusionary power structure taking form.

\section{A conclusion, but not an ending}

'The boat was rocked and the ship sort of sank. Most of the people were thrown overboard. Only a loyal handful remained. The rest are now treading water waiting for a better boat to sail by and jump back in. Others swam away fast grateful for the opportunity to escape. There might be one or two who found a life raft and one or two building a new boat.'

A key challenge we face is how to draw lessons from our experiences that might be constructive, rather than deflating, for others engaged in housing struggles. Routledge and Driscoll Derickson note that scholar-activists should ask themselves how knowledge that is produced through such engagements might be used so that it does not 'reinscribe the interests of the privileged' (2015, p. 393). Indeed, this is a particular challenge with regards to work such as ours which deals with activism imploding. How do we make sure that our lessons are taught in such a way as to enable, not hinder, future activist efforts?

We think it is important to acknowledge that our participation in activism had the positive effect of orientating university resources and academic privileges and training towards the local housing struggle that we wanted to support (see Derickson and Routledge 2015). While our paper describes the challenges of activism and scholar-activism in particular, we maintain that academic participation in political struggles can have beneficial material consequences for non-academic participants, particularly if they are underresourced.

We also feel that it is important to see activism as a generative opportunity to reshape political identities (Featherstone 2003). Rather than seeing ourselves as locked in binary relations of scholars and activists, or scholars and research subjects, we should challenge and explore political identities with a view to generating new ways of being together. This could entail seeing ourselves as more than just academics and placing weight on the activist in scholar-activist. In particular, we urge scholar-activists to work with those individual members who are excluded by existing power distributions within a group and/or within society at large, to create an openness to their subject positions and political influences. New ways of being together that recognise, but begin to challenge, the multi-layered powerdynamics within activist groups, including those existing between researchers and research subjects, is one method through which to create an activist practice grounded in ideals of social justice, while preventing academic appropriation of a struggle.

In order to support and make academic participation in activism possible, we suggest a series of re-orientations for researchers and universities. Re-orientating research objectives to 
synchronise the aims 'on both sides' of the scholar-activist hyphen might help find productive ways forward, rather than viewing these subject positions as potentially contradictory. Designing ethics frameworks so that they centre social justice agendas in ways that are compatible with activism can help address or mitigate some of the exploitative and extractive 'arms length' tendencies of research. And furthermore, we suggest the building of non-exclusionary networks across and beyond academia for scholar-activists and others to share knowledge and develop strategies and practices that support the work of social activism in general, and scholar-activism in particular.

While we did not commence a process of speaking with the excluded members of the imploded activism, we have in varying capacities been supporting another group initiated by women living in public and private housing in the same neighbourhood. The membership of this group is drawn substantially from activists who felt alienated by the way in which other activists operated. So far, this has been a productive venture, although we are still navigating the difficult terrain of self-reflexive solidarity politics. We hope to carry some of the lessons we have learned from our former experiences forward into this group by practising a more intersectional reflexivity that seeks to reshape the multiple power-relations that exist within the group, of which those between academics and working class nonresearcher activists is but one. We have played an active role in supporting this new group by helping organise protests and meetings with local government members, as well as by putting our university's printing equipment to its service. We have been more forward in voicing opinions within the group, but have on a couple of occasions been pulled up by members for overstepping the mark. When and how to take initiative, to voice objection or to hold oneself back are knowledge practices that we are all still developing, and it seems to us that such ways of being can only be developed through active, self-reflexive and longterm political engagement with the people and groups we stand in solidarity with.

\section{Acknowledgements}

We thank Marilu Melo Zurita for suggesting the title of this paper.

\section{References}

Ahmed, S. (2012) On being included: Racism and diversity in institutional life, (Durham, NC: Duke University Press).

Ahmed, S. (2017) Living a feminist life, (Durham: Duke University Press).

Arthurson, K., Darcy, M., \& Rogers, D (2014) Televised territorial stigma: how social housing tenants experience the fictional media representation of estates in Australia. Environment and Planning A, 46(6), 1334-1350.

Australian Research Council, (2018) EI 2018 Framework, Australian Research Council.

Bakhtin, M. (1984) Problems of Dostoevsky's poetics (C. Emerson, Trans.), (Minneapolis: University of Minnesota Press).

Braidotti, R. (2006) Posthuman, all too human: Towards a new process ontology. Theory, culture \& society, 23(7-8), 197-208.

Braidotti, R. (2018) The Human in the Age of Technology and Climate Change. Thinking Out Loud. Powerhouse Museum, Sydney, Australia. Available at: 
https://www.westernsydney.edu.au/philosophy/home/thinking_out_loud/2018_braid otti_human.

Chatterton, P., Fuller, D., \& Routledge, P. (2007) Relating Action to Activism: Theoretical and Methodological Reflections, in: S. Kindon, R. Pain, \& M. Kesby (Eds), Participatory action research approaches and methods: Connecting people, participation and place pp. 216-222 (London; New York: Routledge).

Chatterton, P., Hodkinson, S., \& Pickerill, J. (2010) Beyond Scholar Activism: Making Strategic Interventions Inside and Outside the Neoliberal University, ACME: An International E-Journal for Critical Geographies, 9(2), 245-275.

Collins, C. (1999) Applying Bakhtin in urban studies: the failure of community participation in the Ferguslie Park Partnership, Urban studies, 36(1), 73-90.

Derickson, K. D., \& Routledge, P. (2015) Resourcing Scholar-Activism: Collaboration, Transformation, and the Production of Knowledge, The Professional Geographer, 67(1), 17.

Farrow, H., Moss, P., \& Shaw, B. (1995) Symposium on Feminist Participatory Research, Antipode, 27(1), 71-74.

Featherstone, D. (2003) Spatialities of transnational resistance to globalization: the maps of grievance of the Inter-Continental Caravan, Transactions of the Institute of British Geographers, 28(4), 404-421.

Gillan, K., \& Pickerill, J. (2012) The difficult and hopeful ethics of research on, and with, social movements, Social Movement Studies, 11(2), 133-143.

Gilligan, C. (1995) Hearing the difference: Theorizing connection, Hypatia, 10(2), 120-127.

Haraway, D. J. (2016) Staying with the trouble: Making kin in the Chthulucene, (Duke University Press).

Jacobs, K., Arthurson, K., Cica, N., Greenwood, A., \& Hastings, A. (2011) The stigmatisation of social housing: Findings from a panel investigation, AHURI Final Report.

Katz, C. (1992) All the World is Staged: Intellectuals and the Projects of Ethnography. Environment and Planning D: Society and Space, 10(5), 495-510.

Lave, J. (1991) Situating learning in communities of practice, in: L.B. Resnick, J.M. Levine \& S.D. Teasley (Eds) Perspectives on socially shared cognition, pp. 63-82 (Washington, DC: American Psychological Association).

Martínez López, M. A. (2013) The Squatters' Movement in Europe: A Durable Struggle for Social Autonomy in Urban Politics, Antipode, 45(4), 866-887.

Maxey, I. (1999) Beyond Boundaries? Activism, Academia, Reflexivity and Research, Area, 31(3), 199-208.

Merrifield, A. (1995) Situated Knowledge Through Exploration: Reflections on Bunge's 'Geographical Expeditions', Antipode, 27(1), 49-70.

Munro, L., \& Spring, J. (2018) Survival Guide \#3 Dear Tenant. Radio Skid Row. Available at: https:// soundcloud.com/radio-skid-row/survival-guide-ep-3-dear-tenant?in=radioskid-row/sets/survival-guide

Nagar, R., \& Geiger, S. (2007) Reflexivity and Positionality in Feminist Fieldwork Revisited, in: A. Tickell, E. Sheppard, J. Peck, \& T. Barnes (Eds), Politics and practice in economic geography, pp. 267-278 (Los Angeles ; London: SAGE).

Oldfield, S. (2015) Between activism and the academy: The urban as political terrain, Urban Studies, 52(11), 2072-2086.

Palmer, C., Ziersch, A., Arthurson, K., \& Baum, F. (2004) Challenging the stigma of public housing: preliminary findings from a qualitative study in South Australia, Urban Policy and Research, 22(4), 411-426.

Peck, J., \& Tickell, A. (2002) Neoliberalizing Space, Antipode, 34(3), 380-404.

Postmes, T., \& Smith, L. G. (2009), Why do the privileged resort to oppression? A look at some intragroup factors, Journal of Social Issues, 65(4), 769-790.

Richardson, L. \& St. Pierre, e. A. (2005) Writing: A method of inquiry, in: N.K. Denzin \& Y.S. Lincoln (Eds), The Sage bandbook of qualitative research, pp. 959-978 (Thousand Oaks: Sage Publications). 
Routledge, P. (1996) The Third Space as Critical Engagement, Antipode, 28(4), 399-419.

Routledge, P. \& Derickson, K. D. (2015) Situated solidarities and the practice of scholaractivism, Environment and Planning D: Society and Space, 33(3), 391-407.

Subašić, E., Reynolds, K. J., \& Turner, J. C. (2008) The political solidarity model of social change: Dynamics of self-categorization in intergroup power relations, Personality and Social Psychology Review, 12(4), 330-352.

Wenger, E. (1999) Communities of practice: Learning, meaning, and identity, (Cambridge: Cambridge university press).

Yuval-Davis, N. 2015, Situated Intersectionality and Social Inequality, Raisons Politiques: études de pensée politique, 58 (2), pp. 91. 